Marquette University

e-Publications@Marquette

Civil and Environmental Engineering Faculty

Civil and Environmental Engineering, Department

Research and Publications

$11-1-2016$

Altered Antibiotic Tolerance in Anaerobic
Digesters Acclimated to Triclosan Or Triclocarban

Daniel Elliott Carey

Marquette University

Patrick J. McNamara

Marquette University, patrick.mcnamara@marquette.edu

Accepted version. Chemosphere, Vol. 163 (November 2016): 22-26. DOI. (C) 2016 Elsevier Ltd. Used with permission. 


\title{
Altered Antibiotic Tolerance in Anaerobic Digesters Acclimated to Triclosan Or Triclocarban
}

\author{
Daniel E. Carey \\ Department of Civil, Construction and Environmental \\ Engineering, \\ Marquette University, \\ Milwaukee, WI \\ Patrick J. McNamara \\ Department of Civil, Construction and Environmental \\ Engineering, \\ Marquette University, \\ Milwaukee, WI
}

\begin{abstract}
Bench-scale anaerobic digesters were amended to elevated steadystate concentrations of triclosan $(850 \mathrm{mg} / \mathrm{kg})$ and triclocarban $(150 \mathrm{mg} / \mathrm{kg})$ using a synthetic feed. After more than 9 solids retention time (SRT) values of acclimatization, biomass from each digester (and a control digester that received no antimicrobials) was used to assess the toxicity of three antibiotics. Methane production rate was measured as a surrogate for activity in microcosms that received doses of antibiotics ranging from no-antibiotic to inhibitory concentrations. Biomass amended with triclocarban was more sensitive to tetracycline compared to the control indicating synergistic
\end{abstract}


inhibitory effects between this antibiotic and triclocarban. In contrast, biomass amended with triclosan was able to tolerate statistically higher levels of ciprofloxacin indicating that triclosan can induce functional resistance to ciprofloxacin in an anaerobic digester community.

Keywords: Cross-resistance, Antimicrobial, Ciprofloxacin, Tetracycline, Chloramphenicol

\section{Abbreviations:}

- CDC, Center for Disease Control;

- TCS, triclosan;

- TCC, triclocarban;

- USEPA, United States Environmental Protection Agency;

- IC50, concentration that inhibits $50 \%$ of methane production;

- COD, chemical oxygen demand;

- SRT, solid retention time;

- ATA, anaerobic toxicity assay;

- $\quad$ PATA, prokaryotic anaerobic toxicity assay;

- Kow, octanol water partition coefficient;

- VFA, volatile fatty acid

\section{Introduction}

Antibiotic resistance is a growing public health concern resulting in thousands of deaths every year (CDC, 2013). Antibiotic resistance is influenced and stimulated by many types of stressors including antibiotics, antimicrobials, and metals in a variety of environments (Alanis, 2005, McNamara et al., 2014 and Carey and McNamara, 2015). Of particular concern is the development of cross-resistance whereby resistance to one stressor results in resistance to another stressor (Sefton, 2002). Calls to prudently prescribe antibiotics and minimize their use in agriculture stem in part from desire to quell promotion of cross-resistance and the corresponding spread of 'superbugs'.

Beyond prescription antibiotics, resistance to household antimicrobials has been documented, which yields concern that crossresistance to clinically relevant antibiotics could develop from antimicrobial-Bacteria interaction. TCS and TCC are two household antimicrobial chemicals found in a range consumer products including antibacterial soaps. Cross-resistance to antibiotics stimulated by TCS has been investigated and discovered in many pathogenic bacteria (Giuliano and Rybak, 2015 and Saleh et al., 2011). Although less investigated for its impact on cross-resistance to pathogens, similar concerns for TCC arise (Carey et al., 2016a and Chalew and Halden,

Chemosphere, Vol 163 (November 2016): pg. 22-26. DOI. This article is (C) Elsevier and permission has been granted for this version to appear in e-Publications@Marquette. Elsevier does not grant permission for this article to be further copied/distributed or hosted elsewhere without the express permission from Elsevier. 
2009). The majority of cross-resistance studies have been conducted on pure-cultures, and research documenting cross-resistance in mixed communities is lacking.

The high concentrations of TCC and TCS in municipal wastewater and anaerobic digesters pose a particular concern because of their interaction with a rich and diverse community of Bacteria. TCC and TCS were the most abundant pharmaceuticals (mean concentration of $39,433 \mu \mathrm{g} / \mathrm{kg}$ and $16,097 \mu \mathrm{g} / \mathrm{kg}$ respectively) found in US wastewater biosolids out of 145 chemicals surveyed (USEPA, 2009). Digesters contain a sub inhibitory mixture of antimicrobials and antibiotics that renders development of cross-resistance a strong possibility. Resistance development in biosolids is suspected to have a critical role in antibiotic resistance in terms of public health (Munir et al., 2011, Pruden, 2013 and Ju et al., 2016).

The objective of this research was to determine if long-term TCC or TCS exposure in anaerobic digesters impacted functional resistance (as measured by methane production) to antibiotics. Specifically, the toxicity level $\left(\mathrm{IC}_{50}\right)$ of tetracycline, ciprofloxacin, and chloramphenicol was measured in anaerobic microcosms to determine if exposure to these antimicrobials made microbial communities more or less susceptible to antibiotics. These antibiotics were chosen because they are all separate classes of antibiotics, have variable water chemistries, and are associated with cross-resistance to TCS (see Table 1). Furthermore, most cross-resistance mechanisms that have been identified are efflux pumps that have been upregulated (See Table 1), although it is possible horizontally transferred genes could be responsible for cross resistance.

Table 1. Antibiotic properties.

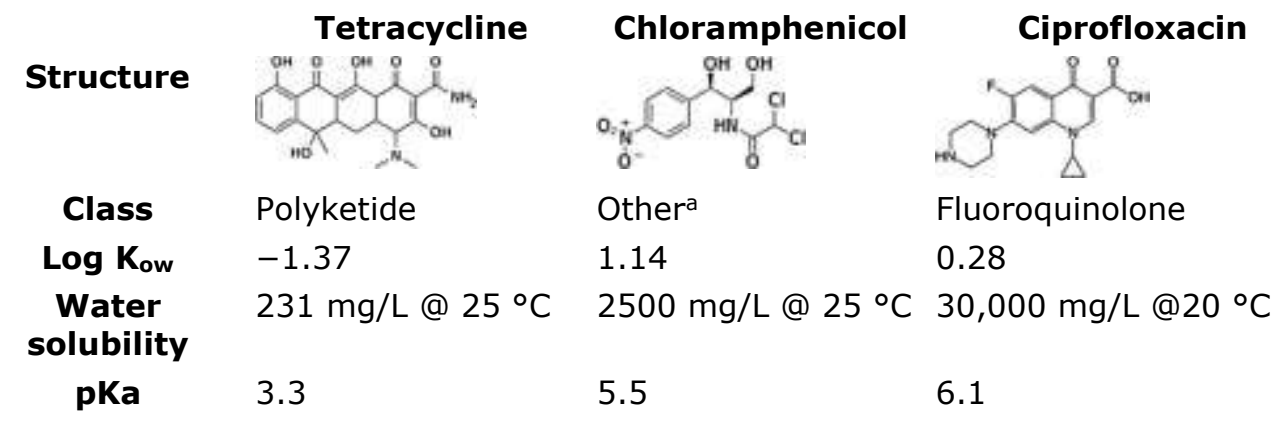

Chemosphere, Vol 163 (November 2016): pg. 22-26. DOI. This article is (C) Elsevier and permission has been granted for this version to appear in e-Publications@Marquette. Elsevier does not grant permission for this article to be further copied/distributed or hosted elsewhere without the express permission from Elsevier. 
NOT THE PUBLISHED VERSION; this is the author's final, peer-reviewed manuscript. The published version may be accessed by following the link in the citation at the bottom of the page.

\begin{tabular}{|c|c|c|c|}
\hline & Tetracycline & Chloramphenicol & Ciprofloxacin \\
\hline $\begin{array}{l}\text { Concentration } \\
\text { in biosolids }\end{array}$ & $1914 \mu \mathrm{g} / \mathrm{kg}$ & $N A^{c}$ & $6858 \mu \mathrm{g} / \mathrm{kg}$ \\
\hline $\begin{array}{l}\text { TCS link to } \\
\text { cross- } \\
\text { resistance }\end{array}$ & $\begin{array}{l}\text { Cross-resistance to } \\
\text { tetracycline forms } \\
\text { from TCS exposure } \\
\text { in pathogens (eg. E. } \\
\text { Coli, P. aeruginosa) }\end{array}$ & $\begin{array}{l}\text { Mechanisms } \\
\text { associated with TCS } \\
\text { resistance are also } \\
\text { associated with } \\
\text { ciprofloxacin } \\
\text { resistance }\end{array}$ & $\begin{array}{l}\text { Chloramphenicol } \\
\text { resistance is stimulated } \\
\text { by exposure to TCS in } \\
\text { pathogenic bacteria (eg } \\
\text { S. Maltophilia, S. } \\
\text { enterica serovar } \\
\text { Typhimurium) }\end{array}$ \\
\hline $\begin{array}{c}\text { Genes } \\
\text { associated } \\
\text { with resistance } \\
\text { to TCS and } \\
\text { antibiotic }\end{array}$ & $\begin{array}{l}\text { acrAB (efflux), } \\
\text { smeDEF (efflux), } \\
\text { nfxB (efflux) }\end{array}$ & acrAB (efflux) & $\begin{array}{l}\text { acrAB (efflux) nfxB } \\
\text { (efflux) }\end{array}$ \\
\hline References & $\begin{array}{l}\text { Braoudaki and } \\
\text { Hilton, 2004, } \\
\text { Chuanchuen et al., } \\
\text { 2001, Kappell et al., } \\
2015 \text {, Sanchez } \\
\text { et al., } \\
2005 \text { and Karatzas } \\
\text { et al., } 2007\end{array}$ & Piddock, 2006 & $\begin{array}{l}\text { Birosová and } \\
\text { Mikulásová, 2009, } \\
\text { Braoudaki and Hilton, } \\
\text { 2004, Karatzas et al., } \\
2007 \text {, Sanchez et al., } \\
2005 \text { and Chuanchuen } \\
\text { et al., } 2001\end{array}$ \\
\hline
\end{tabular}

\section{Materials and methods}

\subsection{Acclimatizing mother reactors to TCC or TCS}

Three mother digesters were established as a biomass source for testing antibiotic toxicity against antimicrobial-acclimatized anaerobic biomass: a control digester, a TCS-amended digester, and a TCC-amended digester. These digesters are referred to as 'mother digesters' throughout this manuscript because the biomass from these digesters was used for inoculum for the experiments that tested antibiotic toxicity. Biomass from these digesters was used to determine the concentration of antibiotics required to inhibit $50 \%$ of methane production during batch methanogenic assays with each amended biomass. Each mother digester had $4 \mathrm{~L}$ of working volume and was seeded with biomass from a full-scale mesophilic anaerobic digester at South Shore Wastewater reclamation facility (Oak Creek, WI). Biomass from this facility was previously measured to have TCC and TCS concentrations of approximately $30 \mathrm{mg} / \mathrm{kg}$ for both antimicrobials in March of 2014 (Carey et al., 2016a and Carey et al., 
2016b). The solid retention time of the mother digesters was 15 days and each digester was given $6 \mathrm{~g}$ of ground and sieved (40 mesh) dog food daily $(1.8 \mathrm{~g} \mathrm{COD} / \mathrm{L}-\mathrm{d})$ in nutrient medium to simulate primary sludge. TCC and TCS was added to each feed to achieve steady state concentrations of $150 \mathrm{mg} \mathrm{TCC} / \mathrm{kg}$ solids and $850 \mathrm{mg} \mathrm{TCS} / \mathrm{kg}$ solids in the method outlined previously (control had no TCC or TCS addition) (Carey et al., 2016a). Digesters were operated for a total of 210 days. Qausi steady-state operation was established over the first 140 days (>9 SRT values), and biomass was used for toxicity testing over the remaining 70 days.

\subsection{Prokaryotic anaerobic toxicity assay (pATA)}

Anaerobic toxicity assay (ATA) style tests were performed to test the toxicity of three antibiotics (Stuckey et al., 1980). Methane production is measured as a surrogate for activity at different doses of a toxicant during batch tests. The experiments performed here differ from traditional ATAs in that a more complex feed carbon source was utilized (dog food) instead of acetate. Dog food was used because degradation to produce methane flows through all trophic groups (Bacterial and Archaeal) in an anaerobic digester. Although Archaea are widely thought to be immune to the actions of the inhibitors used in this experiment (i.e., antibiotics), chloramphenicol has been shown to inhibit Archaea (Hilpert et al., 1981), and the potential for minor or major inhibition in these experiments remains a possibility. Given that trophic groups from Bacteria or Archaea were potentially inhibited (as opposed to only Archaea in a traditional ATA), the modified assays that are performed in this work are referred to as "prokaryotic anaerobic toxicity assays" (pATAs), as prokaryotic refers to Bacteria and Archaea.

Prior to performing a pATA, waste biomass was collected from the mother digesters over a five day period. The biomass was allowed to degas for an additional 3 days before testing. For a given pATA test, a constant volume of biomass $(50 \mathrm{~mL})$ and a constant COD load $(3.5 \mathrm{~g}$ $\mathrm{COD} / \mathrm{L})$ was employed for each glass serum bottle $(160 \mathrm{~mL})$ reactor. For these experiments, seven antibiotic doses were used in triplicate to span several orders of magnitude. The antibiotic employed ranged from no antibiotic to inhibitory concentrations that were determined

Chemosphere, Vol 163 (November 2016): pg. 22-26. DOI. This article is @ Elsevier and permission has been granted for this version to appear in e-Publications@Marquette. Elsevier does not grant permission for this article to be further copied/distributed or hosted elsewhere without the express permission from Elsevier. 
based on preliminary testing. Properties and associations of these antibiotics can be found in Table 1 . Antibiotics were added directly to dog food in a solvent and allowed to dry before use in the pATA. Antibiotics were purchased from Sigma Aldrich (St. Louis, MO).

After each bottle was loaded with biomass, dog food, and antibiotic, the head space was purged with a $70 / 30$ ratio of $\mathrm{N}_{2} / \mathrm{CO}_{2}$ gas and capped with an airtight butyl-rubber stopper. Biogas volume was measured every 6-24 $\mathrm{h}$ for approximately 20 days. When approximately $100 \mathrm{~mL}$ of biogas was produced in any given bottle, the methane percentage was determined with a gas chromatogram coupled to a flame ionization detector (Carey et al., 2016a). Methane production rate was then determined over a period of approximately 20 days. Results were interpreted by determining the linear methane production rate for each antibiotic dose. The concentrations of antibiotic that reduced methane production rate by $50 \%$ (IC $\mathrm{C}_{50}$ ) were determined with Prism ${ }^{\circledR}$ (GraphPad Software, La Jolla, CA). A higher $\mathrm{IC}_{50}$ value indicates a more resistant biomass to a given antibiotic.

\section{Results and discussion}

\subsection{Mother reactor operation}

All three mother digesters (control, TCC-amended, and TCSamended digesters) maintained function, a $\mathrm{pH}$ of approximately 7-7.5 and VFA levels less than $60 \mathrm{mg} / \mathrm{L}$ (see Fig. 1).

Chemosphere, Vol 163 (November 2016): pg. 22-26. DOI. This article is (C Elsevier and permission has been granted for this version to appear in e-Publications@Marquette. Elsevier does not grant permission for this article to be further copied/distributed or hosted elsewhere without the express permission from Elsevier 

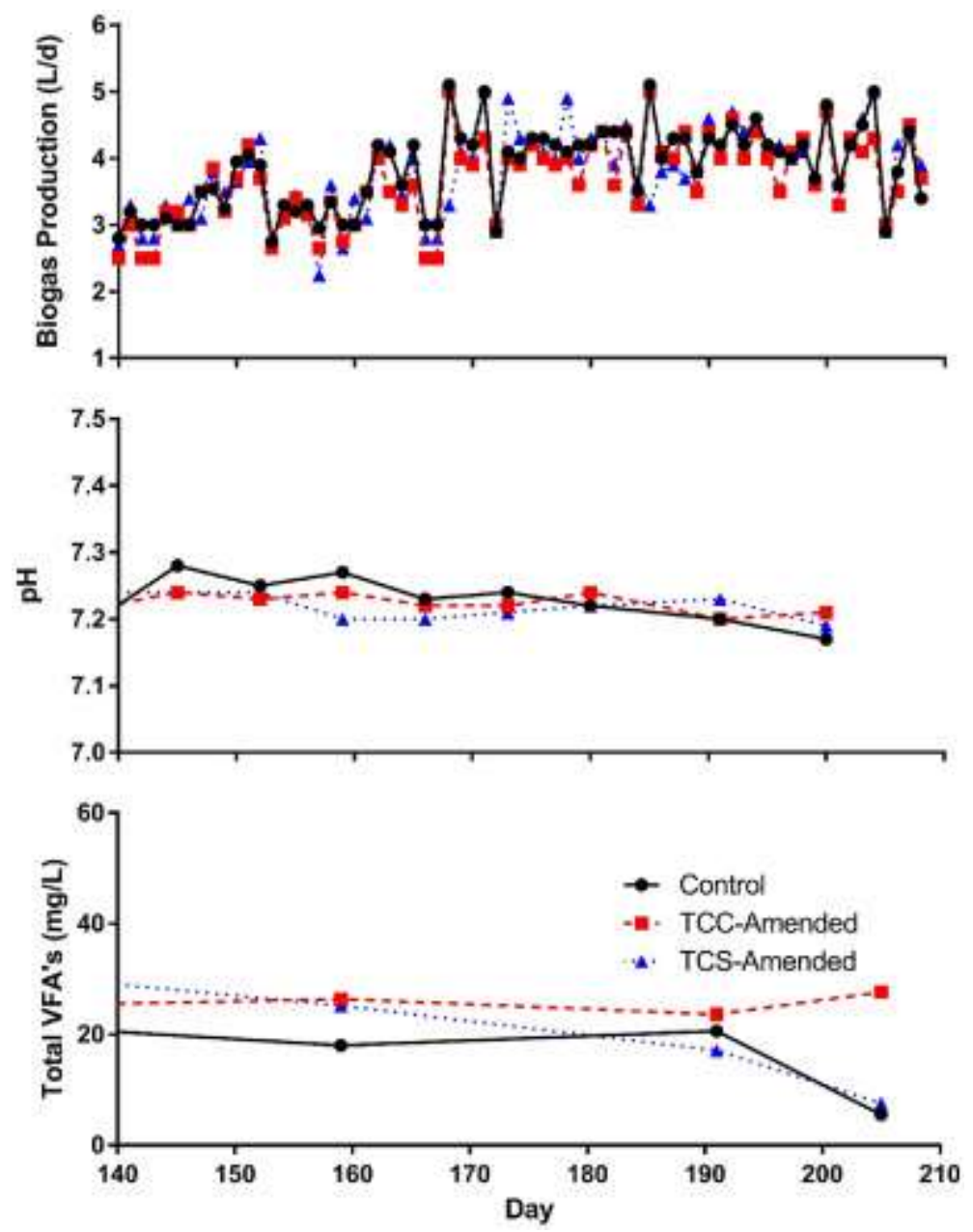

Fig. 1. Biogas, $\mathrm{pH}$ and total VFA concentration from day $140-210$. Total VFAs is the sum of acetic, propionic, butyric, iso-butyric, valeric, and iso-valeric acid.

Biogas production was similar among all digesters, with average biogas production of $3.6 \pm 0.6 \mathrm{~L} /$ day. Methane concentration in biogas was $68 \pm 3.8 \%$ in control digesters, $66 \pm 4.4 \%$ in TCC digesters, and $64 \pm 5.0 \%$ in TCS digesters. Solids concentration in the digesters was at $9.5 \pm 0.1 \mathrm{~g} / \mathrm{L}$ after day 100 and was constant for all pATA tests. In total, three pATA tests were performed with initial biomass draws occurring on day 146 (tetracycline), 177 (chloramphenicol), and 199 (ciprofloxacin).

\subsection{Tetracycline pATA}

The TCC-amended biomass was more susceptible to inhibition by tetracycline relative to the control biomass; the $\mathrm{IC}_{50}$ value (Fig. 2)

Chemosphere, Vol 163 (November 2016): pg. 22-26. DOI. This article is @ Elsevier and permission has been granted for this version to appear in e-Publications@Marquette. Elsevier does not grant permission for this article to be further copied/distributed or hosted elsewhere without the express permission from Elsevier. 
was statistically lower than the control in test sets (control $\mathrm{IC}_{50}=5700 \mathrm{mg} / \mathrm{kg}, \mathrm{TCC}_{\mathrm{IC}} \mathrm{F}_{5}=780 \mathrm{mg} / \mathrm{kg}$ ). Some antibiotics have been shown to have synergistic inhibition effects on anaerobic digestion (Aydin et al., 2015 and Ozbayram et al., 2015). For example, tetracycline has greater inhibition of methanogenesis when used in combination with sulfamethoxazole or erythromycin (Aydin et al., 2015). The mother digester amended with TCC may have been operated at a threshold concentration of TCC, i.e., when this biomass was introduced to another chemical stressor (tetracycline in this case), the biomass was more readily inhibited. Tetracycline is known to work by inhibiting protein synthesis. TCC is thought to intercalate within the cellular membrane; it is possible that TCC made cell membranes more porous and allowed tetracycline to enter into cells more easily. It is difficult to parse the mechanism because there is a paucity of research regarding the mechanism of TCC inhibition on bacteria. Perhaps TCC selected for organisms that maintained the function of the anaerobic digester, yet were intrinsically more sensitive to tetracycline. Tetracycline impacted the TCS-amended biomass differently than the TCC-amended biomass. For TCS-amended biomass, no statistical difference was observed from the control. This result suggests that TCS and tetracycline inhibit cells by independent manners and the chemicals do not have synergistic inhibitory nor additive crossresistance effects.

Chemosphere, Vol 163 (November 2016): pg. 22-26. DOI. This article is (c) Elsevier and permission has been granted for this version to appear in e-Publications@Marquette. Elsevier does not grant permission for this article to be further copied/distributed or hosted elsewhere without the express permission from Elsevier. 
NOT THE PUBLISHED VERSION; this is the author's final, peer-reviewed manuscript. The published version may be accessed by following the link in the citation at the bottom of the page.

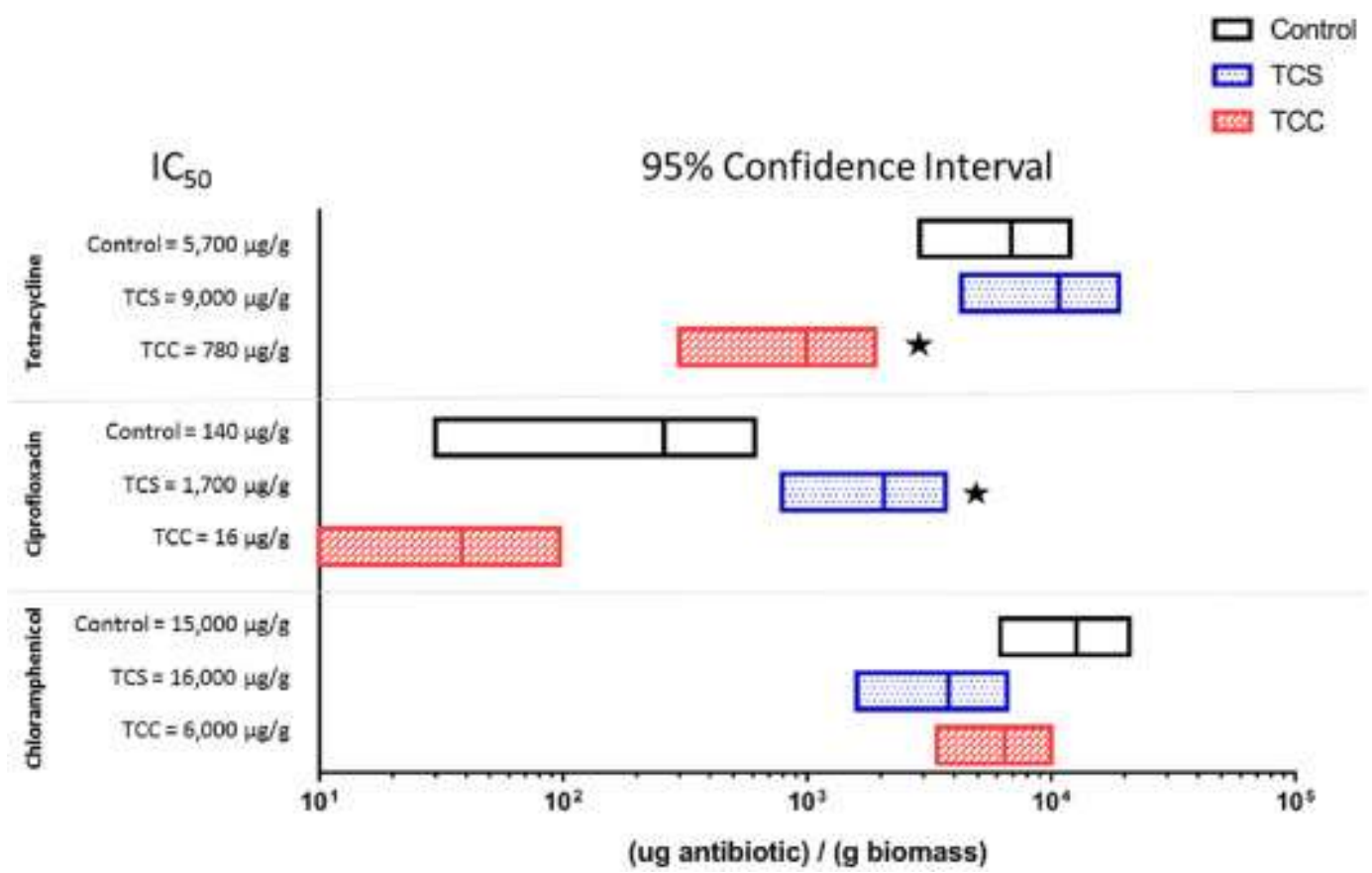

Fig. 2. Previous exposure to antimicrobials alters biomass tolerance to antibiotics; the bars represent the mean $\mathrm{IC}_{50}$ value with flanking $95 \%$ confidence intervals. The mean is also specified on the left side of the graph. Stars to the right of the bar indicate a statistically significant difference from the control, i.e. $p<0.05$. A treatment group that is lower than the control indicates that the biomass became more sensitive to antibiotics after exposure to antimicrobials (such as TCC/tetracycline). A treatment group that is higher than the control bar indicates that the biomass became more resistant to antibiotics after exposure to antimicrobials (such as TCS/ciprofloxacin).

\subsection{Ciprofloxacin PATA}

TCS-amended digesters gained cross-resistance to ciprofloxacin as indicated by digesters having a statistically higher IC $_{50}$ value than the control digesters. This result suggests that resistance mechanisms that allow bacteria to tolerate TCS also allow bacteria to tolerate higher concentrations of ciprofloxacin. In contrast, the $\mathrm{IC}_{50}$ of the TCC biomass was lower as observed with TCC and tetracycline; however, the $95 \%$ confidence intervals heavily overlapped, and this result was not statistically different. Resistance to fluoroquinolones (the family of antibiotics to which ciprofloxacin belongs) is well documented (Kern et al., 2000). While many of the resistance mechanisms rely on target mutation, efflux is also a known resistance mechanism against fluoroquinolones (Jacoby, 2005). In fact, some of the exact same efflux resistance mechanisms that resist ciprofloxacin have been found to resist TCS in pure culture experiments (McMurry et al., 1998). 
Previous experiments showed that Salmonella enterica (a pathogenic bacterium) exposed to $0.5 \mathrm{mg} / \mathrm{L}$ of TCS had increased resistance to ciprofloxacin, and it was concluded that an efflux system (AcrAB) was responsible for this cross-resistance ( Birosová and Mikulásová, 2009). Alternatively, TCS could have shifted the microbial community such that the digester still maintained overall function, but community members were intrinsically more tolerant to ciprofloxacin. Either selection of resistant bacteria or horizontal transfer of resistance genes (e.g. efflux pumps capable of expelling ciprofloxacin and TCS) stimulated by TCS could result in an overall increase in resistance to ciprofloxacin. This finding is especially important when considering that ciprofloxacin and triclosan were two of top three most abundant micropollutants detected in biosolids in a US survey (out of 72 analytes measured) (McClellan and Halden, 2010).

\subsection{Chloramphenicol pATA}

For chloramphenicol, the pATA did not yield statistically significant differences for TCC-amended or TCS-amended biomass compared to the control. The $\mathrm{IC}_{50}$ for the control biomass is higher than the TCS-amended and TCC-amended biomass (by at least $5000 \mu \mathrm{g} / \mathrm{g}$ ); however, the $95 \%$ confidence intervals overlap heavily. The AcrAB efflux pump has been previously associated with both TCS and chloramphenicol resistance,but functional cross-resistance did not develop in these experiments (Piddock, 2006).

\section{Conclusions}

TCC increased the toxicity of tetracycline to anaerobic biomass while TCS induced functional resistance to ciprofloxacin in pATA tests. These results indicate that the mechanisms of action for TCC and TCS are different, however, both scenarios are of concern. For TCC, synergistic action with antibiotics is harsher on digester communities which could lead to a loss of function; for TCS, cross-resistance to antibiotics has public health implications since TCS is so widely used in households and disseminated throughout the environment.

Perhaps resistance may emerge to a class of antibiotics more quickly if cross-resistance is abundant in the environment, and if so,

Chemosphere, Vol 163 (November 2016): pg. 22-26. DOI. This article is (C) Elsevier and permission has been granted for this version to appear in e-Publications@Marquette. Elsevier does not grant permission for this article to be further copied/distributed or hosted elsewhere without the express permission from Elsevier. 
this class of antibiotics should be given special attention in medical use, research, and risk assessment. Determining which classes of antibiotics are the most susceptible to gaining cross-resistance to the most abundant chemical stressors can help guide further research for the protection of public health.

\section{Acknowledgements}

D.E.C was funded by a grant from the Lafferty Family Foundation, the Water Quality Center, and the Dept. of Civil, Construction, and Environmental Engineering at Marquette University.

\section{References}

Alanis, 2005. A.J. Alanis. Resistance to antibiotics: are we in the postantibiotic era? Arch. Med. Res., 36 (6) (2005), pp. 697-705 http://dx.doi.org/10.1016/j.arcmed.2005.06.009

Aydin et al., 2015. S. Aydin, Z. Cetecioglu, O. Arikan, B. Ince, E.G. Ozbayram, O. Ince. Inhibitory effects of antibiotic combinations on syntrophic bacteria, homoacetogens and methanogens. Chemosphere, 120 (2015), pp. 515-520 http://dx.doi.org/10.1016/j.chemosphere.2014.09.045

Birosová and Mikulásová, 2009. L. Birosová, M. Mikulásová. Development of triclosan and antibiotic resistance in Salmonella enterica serovar Typhimurium. J. Med. Microbiol., 58 (4) (2009), pp. 436-441 http://dx.doi.org/10.1099/jmm.0.003657-0

Braoudaki and Hilton, 2004. M. Braoudaki, A.C. Hilton. Low level of crossresistance between triclosan and antibiotics in Escherichia coli $\mathrm{K}-12$ and E. coli 055 compared to E. coli O157. Fems Microbiol. Lett., 235 (2004), pp. 305-309 http://dx.doi.org/10.1016/j.femsle.2004.04.049

Carey and McNamara, 2015. D.E. Carey, P.J. McNamara. The impact of triclosan on the spread of antibiotic resistance in the environment. Front. Microbiol., 5 (780) (2015), pp. 1-11 http://dx.doi.org/10.3389/fmicb.2014.00780

Carey et al., 2016a. D.E. Carey, D.H. Zitomer, K. Hristova, A.D. Kappell, P.J. McNamara. Triclocarban influences antibiotic resistance and alters anaerobic digester microbial community structure. Environ. Sci. Technol., 50 (1) (2016), pp. 126-134 http://dx.doi.org/10.1021/acs.est.5b03080

Carey et al., 2016b. D.E. Carey, D.H. Zitomer, A.D. Kappell, M.J. Choi, K. Hristova, P.J. McNamara. Chronic exposure to triclosan sustains microbial community shifts and alters antibiotic resistance gene levels

Chemosphere, Vol 163 (November 2016): pg. 22-26. DOI. This article is (C) Elsevier and permission has been granted for this version to appear in e-Publications@Marquette. Elsevier does not grant permission for this article to be further copied/distributed or hosted elsewhere without the express permission from Elsevier. 
NOT THE PUBLISHED VERSION; this is the author's final, peer-reviewed manuscript. The published version may be accessed by following the link in the citation at the bottom of the page.

in anaerobic digesters. Environ. Sci. Process. Impacts (2016) http://dx.doi.org/10.1039/C6EM00282]

Center for Disease Control, 2013. Center for Disease Control. US Department of Health and Human Services - Antibiotic Resistance Threats in the United States. (2013) http://www.cdc.gov/drugresistance/pdf/arthreats-2013-508.pdf

Chalew and Halden, 2009. T.E. Chalew, R.U. Halden. Environmental exposure of aquatic and terrestrial biota to triclosan and triclocarban. J. Am. Water Works Assoc., 45 (1) (2009), pp. 4-13 http://dx.doi.org/10.1111/j.1752-1688.2008.00284.x

Chuanchuen et al., 2001. R. Chuanchuen, K. Beinlich, T.T. Hoang, A. Becher, R.R. Karkhoff-Schweizer, H.P. Schweizer. Cross-resistance between triclosan and antibiotics in Pseudomonas aeruginosa is mediated by multidrug efflux pumps: exposure of a susceptible mutant strain to triclosan selects nfxB mutants overexpressing MexCD-Opr].

Antimicrob. Agents Chemother., 45 (2) (2001), pp. 428-432 http://dx.doi.org/10.1128/AAC.45.2.428

Giuliano and Rybak, 2015. C. Giuliano, M.J. Rybak. Efficacy of triclosan as an antimicrobial hand soap and its potential impact on antimicrobial resistance: a focused review. Pharmacotherapy, 35 (3) (2015), pp. 328-336 http://dx.doi.org/10.1002/phar.1553

Hilpert et al., 1981. R. Hilpert, J. Winter, W. Hammes, O. Kandler. The sensitivity of archaebacteria to antibiotics. Zentralblatt für Bakteriologie Mikrobiologie und Hygiene: I. Abt. Originale C: Allgemeine, angewandte und ökologische Mikrobiologie, 2 (1) (1981), pp. $11-20$

Jacoby, 2005. G. Jacoby. Mechanisms of resistance to quinolones. Clin. Infect. Dis., 41 (2005), pp. S120-S126 http://dx.doi.org/10.1086/428052

Ju et al., 2016. F. Ju, B. Li, L. Ma, U. Wang, D. Huang, T. Zhang. Cooccurrence, removal, and enrichment in municipal sewage sludge digesters. Water Res., 91 (2016), pp. 1-10 http://dx.doi.org/10.1016/j.watres.2015.11.071

Kappell et al., 2015. A.D. Kappell, M.S. DeNies, N.H. Ahuja, N. Ledeboer, R.J. Newton, K.R. Hristova. Detection of multi-drug resistant Escherichia coli in the urban waterways of Milwaukee, WI. Front. Microbiol., 6 (April) (2015), pp. 1-12 http://dx.doi.org/10.3389/fmicb.2015.00336

Kern et al., 2000. W.V. Kern, M. Oethinger, A. Jellen-Ritter, S.B. Levy. Nontarget gene mutations in the development of fluoroquinolone resistance in Escherichia coli. Antimicrob. Agents Chemother., 44 (4) (2000), pp. 814-820 http://dx.doi.org/10.1128/AAC.44.4.814820.2000

Karatzas et al., 2007. K.A.G. Karatzas, M. Webber, F. Jorgensen, M.J. Woodward, L.J.V. Piddock, T.J. Humphrey. Prolonged treatment of

Chemosphere, Vol 163 (November 2016): pg. 22-26. DOI. This article is (C) Elsevier and permission has been granted for this version to appear in e-Publications@Marquette. Elsevier does not grant permission for this article to be further copied/distributed or hosted elsewhere without the express permission from Elsevier. 
Salmonella enterica serovar typhimurium with commercial disinfectants selects for multiple antibiotic resistance, increased efflux and reduced invasiveness. J. Antimicrob. Chemother., 60 (5) (2007), pp. 947-955 http://dx.doi.org/10.1093/jac/dkm314

McClellan and Halden, 2010. K. McClellan, R.U. Halden. Pharmaceuticals and personal care products in archived U.S. biosolids from the 2001 EPA national sewage sludge survey. Water Res., 44 (2) (2010), pp. 658$668 \mathrm{http}: / / \mathrm{dx}$.doi.org/10.1016/j.watres.2009.12.032

McNamara et al., 2014. P.J. McNamara, T.M. LaPara, P.J. Novak. The impacts of triclosan on anaerobic community structures, function, and antimicrobial resistance. Environ. Sci. Technol., 48 (13) (2014), pp. 7393-7400

McMurry et al., 1998. L.M. McMurry, M. Oethinger, S.B. Levy. Overexpression of marA, soxS, or acrAB produces resistance to triclosan in laboratory and clinical strains of Escherichia coli. FEMS Microbiol. Lett., 166 (2) (1998), pp. 305-309 Retrieved from http://www.ncbi.nlm.nih.gov/pubmed/9770288

Munir et al., 2011. M. Munir, K. Wong, I. Xagoraraki. Release of antibiotic resistant bacteria and genes in the effluent and biosolids of five wastewater utilities in Michigan. Water Res., 45 (2) (2011), pp. 681693 http://dx.doi.org/10.1016/j.watres.2010.08.033

Ozbayram et al., 2015. E.G. Ozbayram, O. Arikan, B. Ince, Z. Cetecioglu, S. Aydin, $O$. Ince. Acute effects of various antibiotic combinations on acetoclastic methanogenic activity. Environ. Sci. Pollut. Res., 22 (8) (2015), pp. 6230-6235 http://dx.doi.org/10.1007/s11356-014-3841-4

Piddock, 2006. L.J. Piddock. Clinically relevant chromosomally encoded multidrug resistance efflux pumps in bacteria. Clin. Microbiol. Rev., 19 (2) (2006), pp. 382-402 http://dx.doi.org/10.1128/CMR.19.2.382402.2006

Pruden, 2013. A. Pruden. Balancing water sustainability and public health goals in the face of growing concerns about antibiotic resistance. Environ. Sci. Technol., 48 (1) (2013), pp. 5-14 http://dx.doi.org/10.1021/es403883p

Saleh et al., 2011. S. Saleh, R.N.S. Haddadin, S. Baillie, P.J. Collier. Triclosan - an update. Lett. Appl. Microbiol., 52 (2) (2011), pp. 87-95 http://dx.doi.org/10.1111/j.1472-765X.2010.02976.x

Sanchez et al., 2005. P. Sanchez, E. Moreno, J.L. Martinez. The biocide triclosan selects Stenotrophomonas maltophilia mutants that overproduce the SmeDEF multidrug efflux pump. Antimicrob. Agents Chemother. (2005), pp. 781-783 http://dx.doi.org/10.1128/AAC.49.2.781

Chemosphere, Vol 163 (November 2016): pg. 22-26. DOI. This article is (C) Elsevier and permission has been granted for this version to appear in e-Publications@Marquette. Elsevier does not grant permission for this article to be further copied/distributed or hosted elsewhere without the express permission from Elsevier. 
NOT THE PUBLISHED VERSION; this is the author's final, peer-reviewed manuscript. The published version may be accessed by following the link in the citation at the bottom of the page.

Sefton, 2002. A.M. Sefton. Mechanisms of antimicrobial resistance: their clinical relevance in the new millennium. Drugs, 62 (4) (2002), pp. 557-566

Stuckey et al., 1980. D.C. Stuckey, W.F. Owen, P.L. McCarty, G.F. Parkin. Anaerobic toxicity evaluation by batch and semi-continuous assays. Water Pollut. Control Fed., 52 (1980), pp. 720-729

United States Environmental Protection Service, 2009. United States Environmental Protection Service. Targeted National Sewage Sludge Survey Statistical Analysis Report. (2009) https://www.epa.gov/sites/production/files/201504/documents/tnsss_stat_anal_report_revised_april_2009.pdf 